\title{
THE 520-YEAR TEMPERATURE RECORD OF A 100 M CORE FROM THE RONNE ICE SHELF, ANTARCTICA
}

\author{
by
}

W. Graf

(Gesellschaft für Strahlen- und Umweltforschung mbH München (GSF), Institut für Hydrologie, Ingolstädter Landstrasse 1, D-8042 Neuherberg, Federal Republic of Germany)

\section{O. Reinwarth and H. Moser}

(Kommission für Glaziologie der Bayerischen Akademie der Wissenschaften, Marstallplatz 8, D-8000 München 22, Federal Republic of Germany)

\section{ABSTRACT}

Evidence for climatic changes during the last 520 years was inferred from ${ }^{18} \mathrm{O}$ content of a $100 \mathrm{~m}$ ice core from the Ronne Ice Shelf, Antarctica. The core was stratigraphically dated using seasonal variations of ${ }^{18} \mathrm{O}$ content. The mean ${ }^{18} \mathrm{O}$ content of the annual layers calculated on the basis of this dating decreases with depth $z$ according to $\delta^{18} \mathrm{O}\left(\%_{0}\right)=-27.3-0.049 z(\mathrm{~m})$ and reflects first of all the decrease of the ${ }^{18} \mathrm{O}$ content of the near-surface layers in the catchment area of the core from the drilling site $250 \mathrm{~km}$ to the south. This effect was corrected by assuming a linear decrease of the ${ }^{18} \mathrm{O}$ content of the near-surface layers with increasing distance from the drilling site. Corrected $\delta^{18} \mathrm{O}$ values show a large scatter from year-toyear due to the local variability. The smoothed isotopic record displays variations in different time scales, which are caused most probably by climatological induced temperature variations. The gradient of ${ }^{18} \mathrm{O}$ content with the $10 \mathrm{~m}$ firn temperature of $1.15 \% / \mathrm{K}$ found in the middle part of the Filchner-Ronne Ice Shelf was used to transfer the ${ }^{18} \mathrm{O}$ series to a temperature record.

\section{INTRODUCTION}

Stable isotopes of hydrogen and oxygen have proved valuable tools for recording climatic information on different time scales. Apart from the well-known deep ice cores from Greenland and Antarctica, reaching back to the last glacial, interglacial or even to the penultimate glacial period, several cores exist which cover parts of the postglacial period. Some of them are well dated by stratigraphical methods and their ${ }^{18} \mathrm{O}$ contents are closely related to observed temperatures or historical information of meteorological significance (e.g. Dansgaard and others, 1975). But between the ${ }^{2} \mathrm{H}$ contents of two adjacent ice cores from Dome C, Antarctica, no obvious correlation was found (Benoist and others, 1982). Our $100 \mathrm{~m}$ ice core spans 520 years according to stratigraphical dating. From this dating and simple ice-flow modelling, variations of the accumulation rates were deduced (Graf and others, 1988).

In this paper a climatic evaluation of the ${ }^{18} \mathrm{O}$ content of the core will be given, though the drilling site on the Ronne Ice Shelf is not the most favourable, for several reasons. The site is not located in a region of slow-moving ice, but on an ice shelf, which here moves about $600 \mathrm{~m}$ per year seawards (B. Ritter, 1986, personal communication).

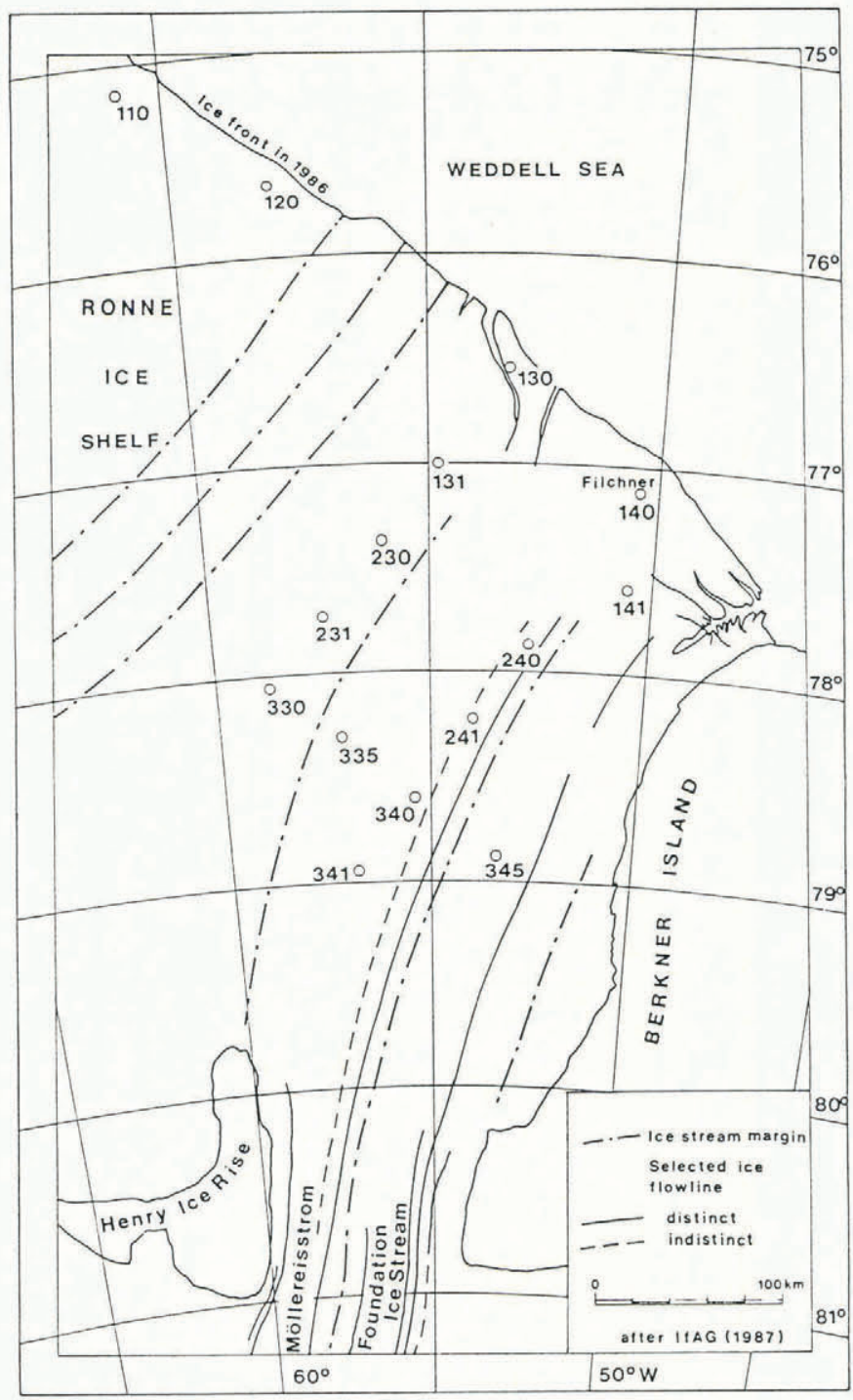

Fig. 1. Measuring points at the Ronne Ice Shelf. The $100 \mathrm{~m}$ ice core was drilled at point 340 . 
Ice gathered from the bottom of the bore hole was therefore deposited far up-stream of the site, and corrections of $\delta^{18} \mathrm{O}$ values are large compared to the climatic signal. For correction of the ${ }^{18} \mathrm{O}$ content of the core, the origin of the ice can be estimated by ice-flow modelling, but distribution of ${ }^{18} \mathrm{O}$ content of the nearsurface layers up-stream of the drilling site is unknown. Finally, the relation between ${ }^{18} \mathrm{O}$ content and mean surface temperature is known only in the northern part of the Ronne Ice Shelf.

Climatic interpretation of the core is therefore limited, but a semi-quantitative evaluation may be possible.

\section{MEAN ${ }^{18} \mathrm{O}$ CONTENTS OF THE ANNUAL LAYERS}

The core was drilled during the $1983 / 84$ field season of the German Antarctic research programme at point 340 on the Ronne Ice Shelf (Fig. 1). The core was dated using seasonal variations of ${ }^{18} \mathrm{O}$ content with an estimated accuracy of $10 \%$ and reaches back, according to this dating, to the year 1461 (Graf and others, 1988). The ${ }^{18} \mathrm{O}$ series was derived from the ${ }^{18} \mathrm{O}$ profile of the core based on the ${ }^{18} \mathrm{O}$ content of 520 annual layers (Fig. 2). This time series reflects first the decrease of ${ }^{18} \mathrm{O}$ content in the catchment area of the core extending $250 \mathrm{~km}$ to the south from the drilling site to the region between Berkner Island and Henry Ice Rise. The ${ }^{18} \mathrm{O}$ series shows secondly a large year-to-year scatter which has to be regarded as noise.

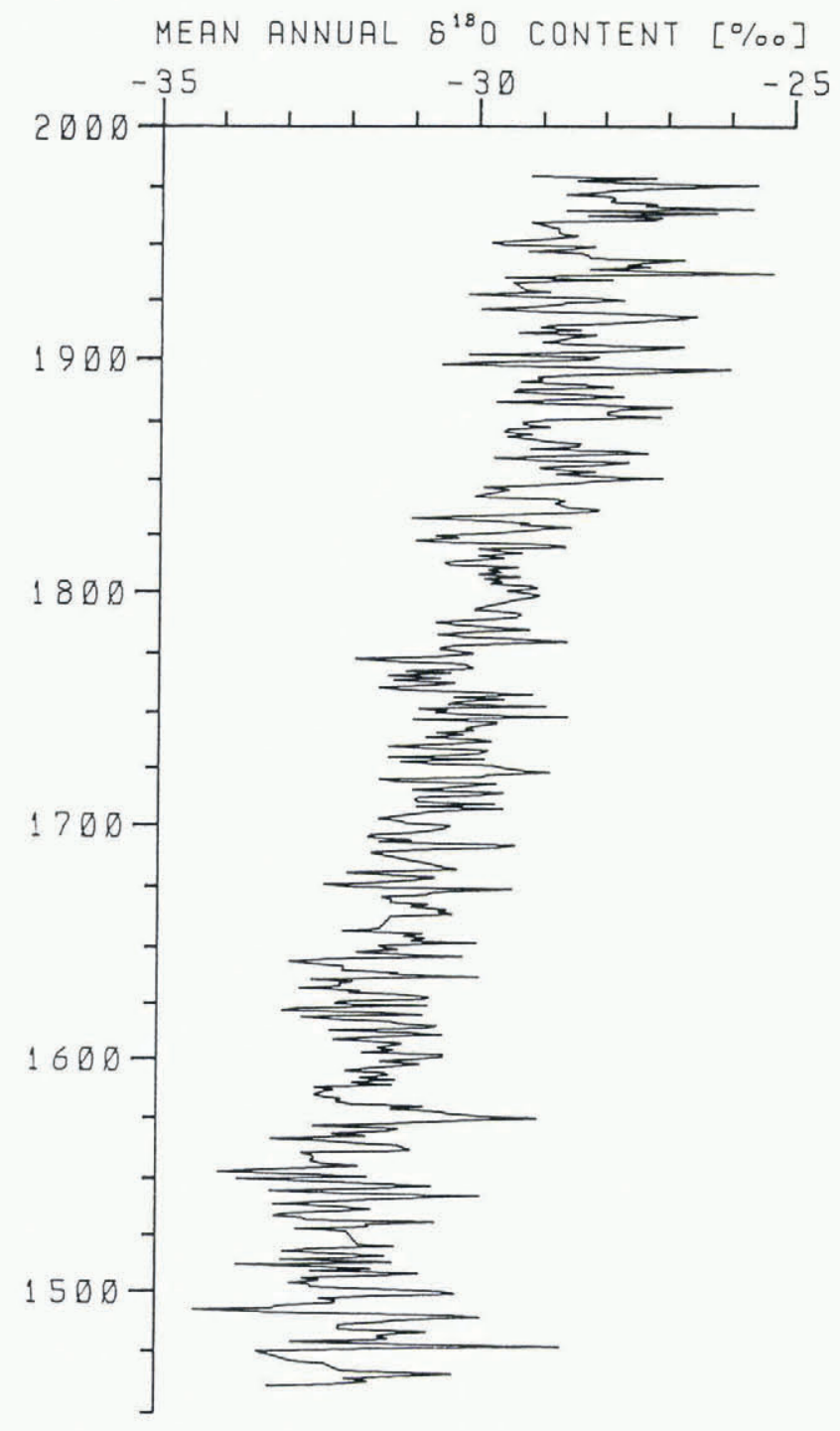

\section{DATE}

Fig. 2. Mean ${ }^{18} \mathrm{O}$ content of the 520 annual layers of the ice core, according to stratigraphical dating.

\section{${ }^{18} \mathrm{O}$ CONTENT UP-STREAM OF THE DRILLING SITE}

For a climatic interpretation, the ${ }^{18} \mathrm{O}$ series has to be corrected for the continental shift of the $\delta^{18} \mathrm{O}$ values. But, as already stated, the distribution of the ${ }^{18} \mathrm{O}$ content of near-surface layers in the catchment area of the core is unknown. The decrease of ${ }^{18} \mathrm{O}$ content with distance from the drilling site has therefore to be estimated. The simplest and only practicable way to do this is to assume a linear dependence of ${ }^{18} \mathrm{O}$ content on the distance from the drilling site and to deduce it from the ${ }^{18} \mathrm{O}$ series itself.

The origin of the annual layers was calculated according to:

$$
t=\int_{x_{2}}^{x_{1}} 1 / v(x) \mathrm{d} x
$$

with $x_{1}-x_{2}$ being the distance between the drilling site and the area in which the $t$ year old layer was deposited. Ice velocity $v(x)$, not measured so far, was taken from three-dimensional modelling of the Ronne Ice Shelf (Lange and MacAyeal, 1986). Regression analysis yields a decrease of ${ }^{18} \mathrm{O}$ content with distance from the drilling site with a gradient of $1.9 \%$ per $100 \mathrm{~km}$. This value is comparable with the gradient of $2.0 \%$ per $100 \mathrm{~km}$ in the northern part of the Ronne Ice Shelf deduced from analysis of snow-pit samples taken in an area from the ice edge to $50 \mathrm{~km}$ south of the drilling site. This agreement may indicate that distribution of ${ }^{18} \mathrm{O}$ content up-stream of the drilling site, inferred from the ${ }^{18} \mathrm{O}$ content of the core itself, is not far from reality, though a linear dependence is not to be expected. The consequences will be discussed later.

\section{THE CLIMATIC SIGNAL}

The series of mean annual ${ }^{18} \mathrm{O}$ contents shows a large scatter from year-to-year. Most can be regarded as noise caused by deposition variations, and variations of $\delta^{18} \mathrm{O}$ values not related to temperature (Robin, 1983). To discover whether this time series contains a climatic signal at all, the signal and the noise variance have to be estimated. For this area, independent information on spatial variability of $\delta^{18} \mathrm{O}$ values from snow-pit samples or firn cores is not available and no additional ice-core record exists to estimate signal-to-noise variance by crosscorrelation coefficient. But it can be assumed that variance of the given time series is the sum of variance of the signal and of the noise:

$$
\sigma^{2}=\sigma_{\text {signal }}^{2}+\sigma_{\text {noise }}^{2}
$$

and that the noise has a white spectral distribution and the climatic information of interest a red one (Fisher and others, 1985). Then the noise can easily be reduced by filtering techniques. Taking running means over $N$ years, variance of the noise decreases with $1 / N$. A random time-series behaves in the expected way under filtering.

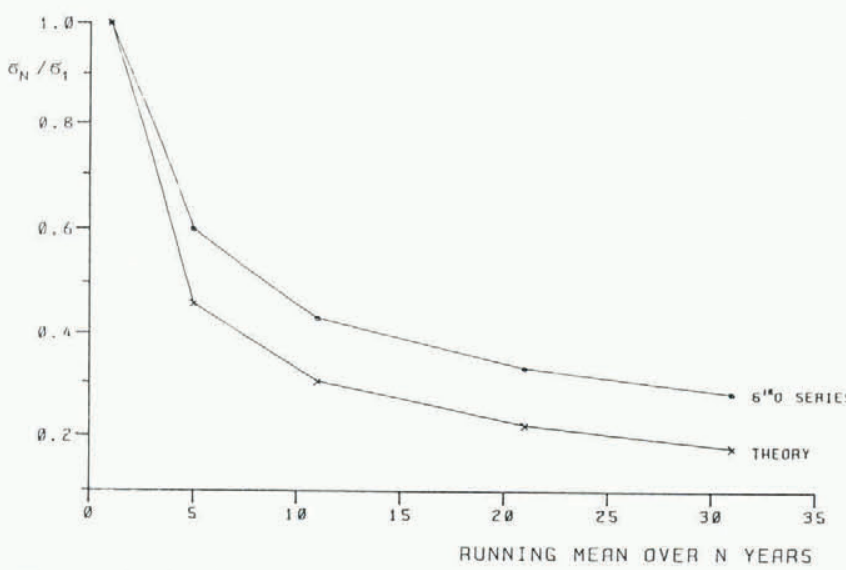

Fig. 3. Reduction of noise in a random time series and in the ${ }^{18} \mathrm{O}$ series from the Ronne Ice Shelf using running means. $\sigma_{\mathrm{N}}=$ standard deviation of the time series smoothed by running means over $N$ years. 


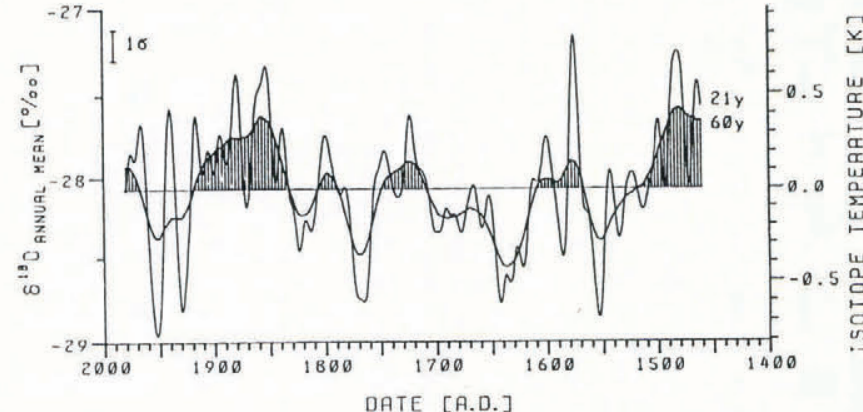

Fig. 4. The up-stream corrected ${ }^{18} \mathrm{O}$ series deduced from core 340 smoothed by Gaussian low pass filters over 21 and 60 years. Indicated is the standard variation due to noise in the series filtered with the 21-year low pass filter. The straight line indicates mean ${ }^{18} \mathrm{O}$ content over the observation period. The isotope temperature record is given as deviation of the mean surface temperature.

Applying the same filtering technique, the variance of the time series from the Ronne Ice Shelf remains above the value expected for a random series (Fig. 3). Therefore it can be concluded that the $\delta^{18} \mathrm{O}$ values contain a signal which may be interpreted in climatic terms.

The smoothed time series using Gaussian low pass filters over 21 and 60 years, respectively, show oscillations of ${ }^{18} \mathrm{O}$ content in different time-scales (Fig. 4). Most dominant are oscillations with a period of about 60 years, which are also evident from the auto-correlation function. A period of 60 years does not appear in the variance spectrum due to the low resolution, but oscillations with a period of 11 years are significant at $90 \%$ confidence level (Fig. 5). From the variance of the original and filtered series, $\sigma_{1}=0.87 \%$ and $\sigma_{1}=0.34 \%$, respectively, a standard deviation due to noise in the smoothed series (21 years mean) of $\sigma_{1}=0.18 \%$ can be inferred. Most of the oscillations are therefore significant.

\section{THE $\delta^{18} \mathrm{O}$-VALUE TEMPERATURE RELATIONSHIP}

The mean ${ }^{18} \mathrm{O}$ contents of the near-surface layers were determined at measuring points in the northern part of the Ronne Ice Shelf (Fig. 1) and at the Soviet station Druzhnaya-I on the Filchner Ice Shelf, respectively from snow-pit samples (Graf and others, 1988) and from a $16 \mathrm{~m}-$ deep firn core (Graf and others, in press). Temperatures of the firn at $10 \mathrm{~m}$ depth, representing mean annual surface temperatures, are available along the Filchner-I-Traverse from Filchner station to the point $341,250 \mathrm{~km}$ south of Filchner station and at Druzhnaya-I (Table I).

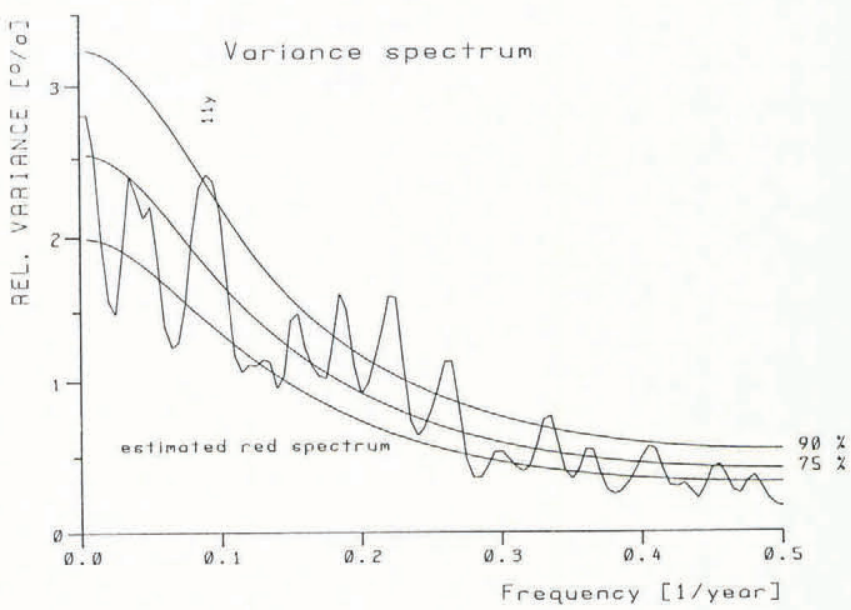

Fig. 5. Variance spectrum of the ${ }^{18} \mathrm{O}$ series deduced from core 340. The estimated red spectrum and confidence levels are calculated according to standard methods (e.g. Schoenwiese, 1985). Oscillations with a period of about 11 years are significant at a $90 \%$ confidence level.
TABLE I. MEAN ${ }^{18} \mathrm{O}$ CONTENTS AND $10 \mathrm{M}$ FIRN TEMPERATURES AT MEASURING POINTS AT THE FILCHNER-RONNE ICE SHELF

$\begin{array}{llcc}\text { Location } & \text { Period } & 10 \mathrm{~m} \text { temperature } & \begin{array}{c}{ }^{18} \mathrm{O} \\ \text { content } \\ \%_{\infty}\end{array} \\ \text { Druzhnaya-I } & 1952-85 & -23.9 & -22.8 \pm 1.9 \\ \text { Filchner } & 1979-83 & -25.0 & -24.6 \pm 0.9 \\ 141 & 1979-83 & -25.8 & -25.4 \pm 1.3 \\ 240 & 1979-85 & -25.9 & -27.2 \pm 1.6 \\ 241 & 1979-85 & -26.3 & -27.8 \pm 1.2 \\ 340 & 1979-85 & -26.9 & -28.5 \pm 1.1 \\ 341 & 1978-85 & -27.4 & -28.9 \pm 2.0\end{array}$

Regression analysis yields a decrease of ${ }^{18} \mathrm{O}$ content with temperature of $1.88 \% / \mathrm{K}$ over a wide area with a correlation coefficient $r=0.97$ (Fig. 6). This gradient is very large in relation to values deduced from theoretical considerations and compared to values found in other coastal regions of Antarctica (Robin, 1983). The Rayleigh model predicts a gradient of less than $1.0 \% / \mathrm{K}$ using the decrease of condensation temperatures, which equal the temperatures above the inversion (Robin, 1977) and are linearly related to surface temperatures (Phillpot and Zillman, 1970). In accordance with this consideration, measured temperature gradients of ${ }^{18} \mathrm{O}$ contents in other coastal areas of Antarctica are less than $1 \% / \mathrm{K}$. We conclude that the figure of $1.88 \% / \mathrm{K}$ on the Filchner-Ronne Ice Shelf reflects other processes than those considered in the Rayleigh model, for

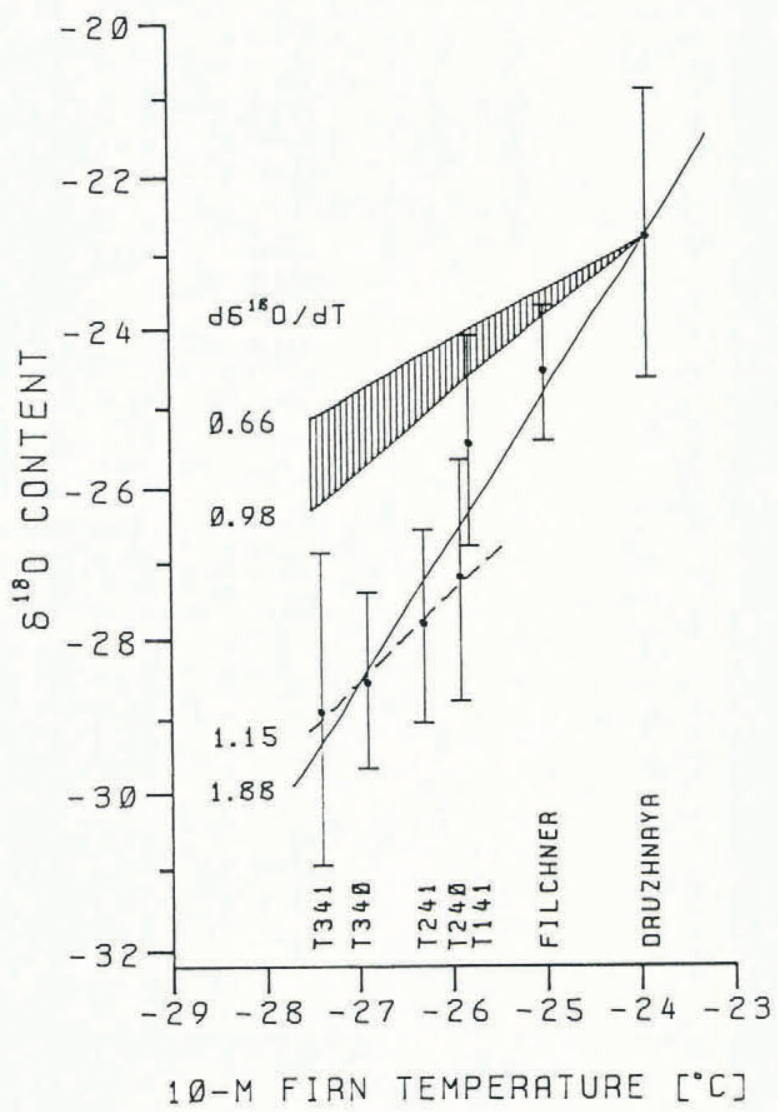

Fig. 6. $\delta^{18} \mathrm{O}$ temperature relationship on the Filchner-Ronne Ice Shelf based on measurements at sites listed in Table I. The temperature gradient of $1.88 \% / \mathrm{K}$ is remarkably higher than theoretical expected values between 0.66 and $0.98 \% / \mathrm{K}$ (hatched area) estimated according to the Rayleigh model using the real condensation temperatures $T_{\mathrm{C}} \quad\left(T_{\mathrm{C}}=0.67 T_{\text {surface }}-1.2\right)$ and assuming that condensation leads to the formation of water-droplets respectively before freezing and immediately to ice crystals. In the middle of the ice shelf a gradient $1.15 \% / \mathrm{K}$ is displayed. 
instance, the variation of the ratio of winter-to-summer accumulation in the investigated area or changing atmospheric circulation patterns during the seasons. But the snow-pit data are too scarce to prove these assumptions. The gradient in the region between 120 and $270 \mathrm{~km}$ from the ice edge on the Ronne Ice Shelf, with a value of $1.15 \% / \mathrm{K}$ is remarkably lower than that over the entire investigated area; it is closer to the theoretical range and was used to transfer the ${ }^{18} \mathrm{O}$ series to a climatic record.

\section{DISCUSSION}

With the temperature gradient the ${ }^{18} \mathrm{O}$ series can be presented as a time series of temperature covering 520 years as shown in Figure 4. The mean temperature for this period is indicated by the straight line. Pronounced deviations to lower temperatures are exhibited for most of the time, especially between 1500 and 1829 A.D. Some uncertainties arise, because the up-stream correction of the $\delta^{18} \mathrm{O}$ values was made assuming a linear decrease of ${ }^{18} \mathrm{O}$ content on the Ronne Ice Shelf south to the drilling site. The distribution of ${ }^{18} \mathrm{O}$ contents certainly shows in reality a more complicated pattern. In this case the ${ }^{18} \mathrm{O}$ series corrected with the linear trend would reflect variations of higher order. But oscillations due to climatic changes are indicated most probably, if mean annual ${ }^{18} \mathrm{O}$ content increases with increasing distance from the drilling site (Fig. 6). The only non-climatic explanation would require that the flow line of

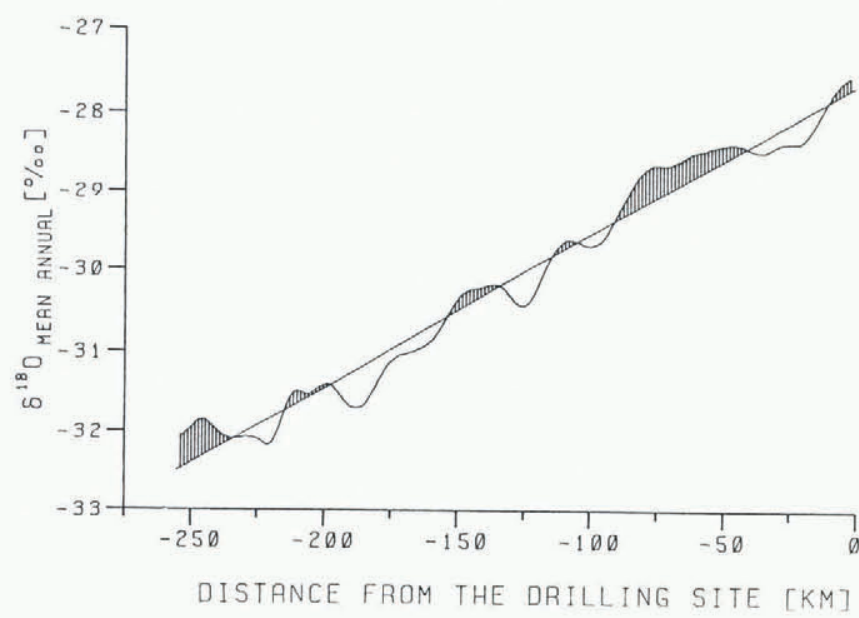

Fig. 7. The mean ${ }^{18} \mathrm{O}$ content of the 520 annual layers of core 340 versus the location of deposition of these layers. The curve is smoothed using a Gaussian low pass filter over 60 years. The straight line indicates the assumed continental shift of ${ }^{18} \mathrm{O}$ content up-stream of the drilling site. ice through the drilling site several times crosses lines of equal ${ }^{18} \mathrm{O}$ content. This possibility cannot be ruled out completely, but is unlikely if, for comparison, the distribution pattern of the ${ }^{18} \mathrm{O}$ content on the Ross Ice Shelf (Clausen and others, 1979) is regarded. Therefore, most of the oscillations at periods of 60 years can be attributed to temperature variations. However, regarding the long-term change in the ${ }^{18} \mathrm{O}$ record, which is in the order of the observation period, it is difficult to distinguish between local and climatic influences. Its reliable interpretation in climatic terms would require the experimental determination of the distribution of ${ }^{18} \mathrm{O}$ content up-stream of the drilling site.

\section{ACKNOWLEDGEMENTS}

This work was financially supported by the Deutsche Forschungs-Gemeinschaft (DFG). The authors thank also the the Alfred-Wegener-Institut für Polar- und Meeresforschung, Bremerhaven, for logistic support.

\section{REFERENCES}

Benoist, J.P., J. Jouzel, C. Lorius, L. Merlivat, and M. Pourchet. 1982. Isotope climatic record over the last $2.5 \mathrm{ka}$ from Dome C, Antarctica, ice cores. Ann. Glaciol., 3 , $17-22$.

Clausen, H.B., W. Dansgaard, J.O. Nielsen, and J.W. Clough. 1979. Surface accumulation on Ross Ice Shelf. Antarct. J. U. S., 14(5), 68-72.

Dansgaard, W., S.J. Johnsen, N. Reeh, N. Gundestrup, H.B. Clausen, and C.U. Hammer. 1975. Climatic changes, Norsemen and modern man. Nature, 255(5503), 24-28.

Fisher, D.A., N. Reeh, and H.B. Clausen. 1985. Stratigraphic noise in time series derived from ice cores. Ann. Glaciol., 7, 76-83.

Graf, W., H. Moser, H. Oerter, O. Reinwarth, and W. Stichler. 1988. Accumulation and ice-core studies on Filchner-Ronne Ice Shelf, Antarctica. Ann. Glaciol., 11, 23-31.

Lange, M.A. and D.R. MacAyeal. 1986. Numerical models of the Filchner-Ronne Ice Shelf: an assessment of reinterpreted ice thickness distributions. J. Geophys. Res., 91(B10), 10,457-10,462.

Phillpot, H.R. and J.W. Zillman. 1970. The surface temperature inversion over the Antarctic continent. $J$. Geophys. Res., 75(21), 4161-4169.

Robin, G. de Q. 1977. Ice core and climatic change. Philos. Trans. R. Soc. London, Ser. B, 280(972), 143-168.

Robin, G. de Q. 1983. The climatic record from ice cores. In Robin, G. de Q., ed. The climatic record in polar ice sheets. Cambridge, etc., Cambridge University Press, 180-195.

Schönwiese, C.D. 1985. Praktische Statistik. Berlin, Gebr. Borntraeger. 